health interventions. Thus, the study aimed to determine the distribution of AIDS in Ceará, Brazil.

Methods It was an ecological and longitudinal study. It was analysed all individuals with aids, aged less than 13 years, residents in Ceará, Brazil, reported between 2001 and 2011 by the Information System Notification of the country. We carried out the distribution spatiotemporal cases where data were arranged in cartographic grid. From this, the main cases clusters were identified over the years. It was used ArcGis program.

Results The distribution of aids in the state during the study period allowed the identification of four significant clusters $\mathrm{p}$ $(<0.05)$. The primary conglomerate $(\mathrm{p}<0.01)$ was located in Fortaleza, the state capital, with $15,42 \mathrm{Km}$ radius, covering surrounding municipalities, being an active cluster in each year. Three other side identified clusters $(p=0.049)$ were: Jijoca Jericoacoara; Groaíras, less than $1 \mathrm{~km}$ radius; municipalities of Limoeiro do Norte, Tabuleiro, Quixeré, São João do Jaguaribe and Russas, with radius of $36,8 \mathrm{~km}$.

Conclusion The distribution of aids cases in Ceará does not occur randomly, but occurs in clusters over the years, suggesting studies to identify the determinants local features the largest number of cases.

Disclosure of interest statement This study was funded by CAPES (Higher Education Personnel Training Coordination) and CNPq (National Council for Scientific and Technological Development). No pharmaceutical grants were received in the development of this study.

\section{P16.15 CHILDREN AND YOUNG PEOPLE LIVING WITH HIVIAIDS IN A STATE OF NORTH-EASTERN BRAZIL}

CMD Florêncio, HO Alexandre*, ICV Lima, VF Santos, MTG Galvão, SAR Pereira, FMS Oliveira,. Federal University of Ceará

\subsection{6/sextrans-2015-052270.562}

Introduction With the advent of antiretroviral therapy there was a significant improvement in the quality of life of children and young people living with HIV/aids, allowing these patients reach adulthood. This public needs to live with the stigma and often with the lack of a structured household and better living conditions. As a consequence, they expose themselves to the risk of acquiring other diseases. This study aimed to describe the epidemiological profile of children and young people aged between 0 to 19 years, diagnosed with HIV/aids living in the state of Ceará in Brazil.

Methodology Data were collected from the Notifiable Diseases Information System (Sinan) from 2003 to 2012. For comparison between gender traits studied, it was used the odds ratio tests and chi-square with significant value or p-value $<005$.

Results A total of 10,284 people were diagnosed with HIV in Ceará during the period. Of this total, $4.62 \%$ were children and young adults up to 19 years. The sex ratio was 1.92: 1 with a predominance of males in the general population, while in the group studied the proportion was lower, being 1.04: 1. Girls with ages from 0 to five years (odds ratio: 0.5725 ; $\mathrm{p}$-value $=$ 0.0003 ), six to 12 years (odds ratio: $0.5281 ; \mathrm{p}=0.002$ ) and 13 to 19 (Odds ratio: 0.5079; $\mathrm{p}<0.0001$ ) were more likely to be diagnosed with HIV than those of other ages.

Conclusion The male population is predominantly affected by HIV, however these proportions can vary depending on each age group, as girls and young women are more likely to be diagnosed with the virus. Thus, it is necessary the creation of public policies for this audience and aimed at preventing infection by the virus.

Disclosure of interest statement This study was funded by CAPES (Higher Education Personnel Training Coordination) and CNPq (National Council for Scientific and Technological Development). No pharmaceutical grants were received in the development of this study.

\section{P16.16 ASPECTS RELATED TO THE QUALITY OF LIFE OF PATIENTS WHO USE ANTIRETROVIRAL THERAPY}

SC Pedrosa, HO Alexandre*, ICV Lima, MLT Fiuza, GH Cunha, MTG Galvão. Federal University of Ceará

\subsection{6/sextrans-2015-052270.563}

Introduction The antiretroviral therapy (ART), although is not a cure, allows the slow of the disease's course, while extending and promotes a better quality of life for the patient. Given that, the quality of health-related life is a concept that has as focus the subjective evaluation of the patient and is necessarily related to the impact of health status on the individual's ability to live fully, this study aimed to evaluate the satisfaction of the aspects related to quality of life in patients who use of ART.

Methods This is a cross-sectional study, with a descriptive character. The study included 215 patients who met the following inclusion criteria: in use of ART, age or over 18 years. The study met all legal and ethical issues.

Results Most participants were male $(144 ; 66.98 \%)$ with a mean age of 40 years. The vast majority of respondents reported being satisfied or very satisfied: with sleep $(127 ; 59 \%)$; the ability to perform activities of daily life $(151 ; 70.23 \%)$, the ability to work (132; 61.40\%).

Conclusion To conclude, antiretroviral therapy contributes to the improvement of personal satisfaction related to health parameter.

Disclosure of interest statement This study was funded by CAPES (Higher Education Personnel Training Coordination) and CNPq (National Council for Scientific and Technological Development). No pharmaceutical grants were received in the development of this study.

\section{P16.17 CORRELATION BETWEEN DEMOGRAPHICS, CLINICAL AND RISK FACTOR FOR HIV INFECTED WITH HIV/TB CO- INFECTED IN AMERTHA CLINIC KERTI PRAJA FOUNDATION BALI}

${ }^{1}$ ON Yuneti*, 1,2IWG Artawan Eka Putra, ${ }^{1,3}$ AAS Sawitri, 1,3,4DN Wirawan. 'Udayana University, Post Graduate School of Public Health, Bali, Indonesia; ${ }^{2}$ Udayana University, School of Public Health Faculty of Medicine Bali, Indonesia; ${ }^{3}$ Udayana University, Department of Community and Preventive Medicine Faculty of Medicine, Bali, Indonesia; ${ }^{4}$ Kerti Praja Foundation Bali, Indonesia

\subsection{6/sextrans-2015-052270.564}

Introduction HIV infection increases the risk of developing Tuberculosis (TB), as TB infection increases the progression of HIV. In Indonesia, the rate of patients HIV positive with TB (HIV/TB co-infected) have reported $31.8 \%$ in 2013. In Bali HIV/TB co-infected patients have increased from $26 \%$ in 2012 to $30 \%$ in 2013 . This study aims to determine the correlation between demographics, clinical and risk factor for HIV infected with HIV/TB co-infected in Amertha Clinic Kerti Praja Foundation Bali. 